\title{
Combination of Pelargonium sidoides and Coptis chinensis root inhibits nuclear factor kappa B-mediated inflammatory response in vitro and in vivo
}

Sang Mi Park ${ }^{1 \dagger}$, Byung-Gu Min ${ }^{2 \dagger}$, Ji Yun Jung ${ }^{1}$, Kyung Hwan Jegal ${ }^{1}$, Chul Won Lee ${ }^{1}$, Kwang Youn Kim', Young Woo Kim', Youn-Woong Choi ${ }^{3}, \|$ Je Cho', Sae Kwang Ku ${ }^{1}$ and Sang Chan Kim ${ }^{1 *}$

\begin{abstract}
Background: Pelargonium sidoides (PS) and Coptis chinensis root (CR) have traditionally been used to treat various diseases, including respiratory and gastrointestinal infections, dysmenorrhea, and hepatic disorders. The present study was conducted to evaluate the anti-inflammatory effects of a combination of PS and CR in vitro and in vivo.

Methods: The in vitro effects of PS + CR on the induction of inflammation-related proteins were evaluated in lipopolysaccharide (LPS)-stimulated RAW 264.7 cells. The levels of nitric oxide (NO) and of inflammatory cytokines and prostaglandin $E_{2}\left(P_{G} E_{2}\right)$ were measured using the Griess reagent and enzyme-linked immunosorbent assay (ELISA) methods, respectively. The expression of inflammation-related proteins was confirmed by Western blot. Additionally, the effects of PS + CR on paw edema volume, skin thickness, and numbers of infiltrated inflammatory cells, mast cells, COX-2-, iNOS-, and TNF-a-immunoreactive cells in dorsum and ventrum pedis skin were evaluated in a rat model of carrageenan (CA)-induced paw edema.

Results: PS + CR significantly reduced production of $\mathrm{NO}, \mathrm{PGE}_{2}$ and three pro-inflammatory cytokines (tumor necrosis factor-a (TNF-a), interleukin (IL)-1 $\beta$, and IL-6) and also decreased levels of inducible nitric oxide synthase (iNOS) and cyclooxygenase-2 (COX-2). Treatment with PS + CR significantly reduced the protein expression levels of LPS-stimulated nuclear factor kappa B (NF-KB) and phosphorylated inhibitor of NF-KB ( $\mathrm{p}-\mathrm{-}-\mathrm{kBa})$. Additionally, PS + CR significantly inhibited the increases in paw swelling, skin thickness, infiltrated inflammatory cells, mast cell degranulation, COX-2-, iNOS-, and TNF-a-immunoreactive cells in the rat model of CA-induced acute edematous paw.

Conclusions: These results demonstrate that PS + CR exhibits anti-inflammatory properties through decreasing the production of pro-inflammatory mediators (NO, PGE, TNF-a, IL-1 $\beta$, and IL-6), suppressing NF-KB signaling in LPS-induced RAW 264.7 cells. Additionally, the results of the CA-induced rat paw edema assay revealed an anti-edema effect of PS + CR. Furthermore, it is suggested that PS + CR also inhibits acute edematous inflammation by suppressing mast cell degranulation and inflammatory mediators (COX-2, iNOS, and TNF-a). Thus, PS + CR may be a potential candidate for the treatment of various inflammatory diseases, and it may also contribute to a better understanding of the molecular mechanisms underlying inflammatory response regulation.
\end{abstract}

Keywords: Pelargonium sidoides, Coptis chinensis root, Inflammation, Nuclear factor kappa B, Paw edema, Histopathology

* Correspondence: sckim@dhu.ac.kr

${ }^{\dagger}$ Equal contributors

${ }^{1}$ College of Korean Medicine, Daegu Haany University, Gyeongsan 38610,

Republic of Korea

Full list of author information is available at the end of the article 


\section{Background}

Inflammation is an important immune response for defending against harmful stimuli, such as pathogenic bacteria, viruses, and fungi $[1,2]$. Once infected with a pathogen, the skin and mucosal surfaces serve as primary physical barriers in the immune response that maintains homeostasis [3]. However, excessive inflammation is a key player in the development of multiple diseases, including cancer, diabetes, inflammatory bowel diseases, and cardiovascular diseases [4]. Inflammation is tightly regulated by signals that initiate, maintain, or inhibit the inflammatory process $[5,6]$. Inflammation has diverse triggers, including infection, physical and chemical injuries, ischemia, and excessive immune response [3, 4].

Under inflammatory conditions, several enzymes, cytokines, and chemokines are secreted by macrophages as signaling molecules to resolve abnormal conditions [1, 7]. The model most commonly used to investigate inflammation involves activating macrophage cells with lipopolysaccharides (LPS) to trigger the abnormal generation of nitric oxide $(\mathrm{NO})$, prostaglandin $\mathrm{E}_{2}\left(\mathrm{PGE}_{2}\right)$, tumor necrosis factor $\alpha$ (TNF- $\alpha$ ), and interleukin (IL) $-1 \beta[8,9]$. Recently, there have been several reports regarding the use of traditional medicine or phytomedicine to treat various diseases related to inflammation, such as allergies, asthma, eczema, rheumatoid arthritis, irritable bowel syndrome, and cancer $[10,11]$.

In South Africa, the polyphenol-rich herbal roots of the plant Pelargonium sidoides are traditionally used to treat respiratory and gastrointestinal infections, dysmenorrhea, and hepatic disorders [12, 13]. They have also been used in tuberculosis, and their medicinal properties include antibacterial, antifungal, antiviral, and immune modulatory activities [14]. Additionally, the dried rhizome of Coptis chinensis has been used to treat gastroenteric disorders, cardiovascular diseases, cancer, and liver injuries $[15,16]$. Recent research has shown that these roots have pharmacological properties, such as anti-oxidant, anti-cancer, and anti-inflammatory activities [17-19].

It is expected that a combination of $P$. sidoides (PS) and C. chinensis root (CR) would have anti-inflammatory effects both in vitro and in vivo because it has traditionally been used to reduce fevers [3, 20]. However, the mechanisms underpinning the anti-inflammatory activities of the PS and CR mixture (PS + CR) have not yet been reported. Therefore, in this study, we evaluated the antiinflammatory effects of PS + CR using LPS-stimulated RAW 264.7 cells as well as carrageenan (CA)-induced paw edema as an acute phase inflammation animal model.

\section{Methods}

\section{Chemicals and reagents}

The LPS (E. coli 026:B6), Griess reagent, 3-(4,5-dimethylthiazol)-2,5-diphenyltetrazolium bromide (MTT), epicatechin and berberine were obtained from Sigma (St. Louis, MO, USA). Enzyme linked immunesorbent assay (ELISA) kits for tumor necrosis factor-alpha (TNF- $\alpha$ ), interleukin (IL)-6 and IL-1 $\beta$ were acquired from Pierce Endogen (Thermo Scientific, Waltham, MA, USA). The $\mathrm{PGE}_{2}$ ELISA kit was obtained from $\mathrm{R} \& \mathrm{D}$ Systems (Minneapolis, MN, USA). Anti-p-I-kB $\alpha$, antibody and peroxidase-conjugated secondary antibody were purchased from Cell Signaling (Danvers, MA, USA). Anti-COX-2 and anti-iNOS antibodies were obtained from BD Biosciences

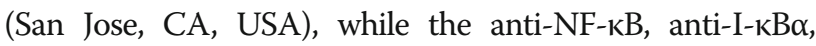
anti- $\beta$-actin and anti-lamin $\mathrm{A} / \mathrm{C}$ antibodies were purchased from Santa Cruz Biotechnology (Dallas, TX, USA). All other chemicals were purchased from the Sigma Chemical Co. (St. Louis, MO, USA).

\section{Preparation of $P S+C R$ and determination of active compounds}

Pelargonium sidoides extract and Coptis chinensis root extract powder were purchased from Sungil Bioex (Hwaseong, Republic of Korea) and identified by Dr. Byung $\mathrm{Gu}$ Min of the Korea United Pharm. Inc. in South Korea. The voucher specimens (KUP TR001 for PS; KUP M003 for $C R$ ) are deposited in the Korea United Pharm. Inc.. Briefly, $P$. sidoides extract is an important aqueousethanolic $(11 \% \mathrm{~m} / \mathrm{m})$ extract with a yield of $8-10 \%$. In addition, $C$. chinensis roots $(1 \mathrm{~kg})$ were extracted with $7 \mathrm{~L}$ of boiling distilled water for $3 \mathrm{~h}$, and filtered through a filter paper (Hyundai Micro No. 20). The supernatant was filtered through a $0.2 \mu \mathrm{m}$ filter (Nalgene, New York, USA), and the filtrate was then lyophilized. The yield of lyophilized C. chinensis root extract was $11.2 \%$. Furthermore, $P$. sidoides extract was treated with $C$. chinensis root extract powder $(2: 1)$. For this, extract (10 g) was dissolved in distilled water $(250 \mathrm{ml})$, Coptis chinensis powder ( $5 \mathrm{~g}$ ) added and the mixture stirred for $45 \mathrm{~min}$ at $25{ }^{\circ} \mathrm{C}$. The sample was then lyophilized and kept at $20{ }^{\circ} \mathrm{C}$ until use. The lyophilized powder was dissolved in sterile water prior to use.

An ultra-performance liquid chromatography (UPLC) analysis was performed using the Waters ACQUITY UPLC system (Waters Corporation, Milford, MA, USA) with a photodiode array detector (PDA), BEH $\mathrm{C}_{18}$ HPLC column $(1.7 \mu \mathrm{m}, 2.1 \mathrm{~mm} \times 100 \mathrm{~mm})$, and Empower software. Samples were extracted with an 8210R-DHT ultrasonic cleaner (Branson Company) using methanol (JT BAKER for the HPLC), acetonitrile (JT-BAKER for the HPLC), dimethylsulfoxide (DMSO; Sigma for the HPLC), and tertiary distilled water. The standard preparations for this experiment were from WAKO Co. (Japan). In the PDA wavelength analysis, epicatechin and berberine were detected at $230 \mathrm{~nm}$ and $345 \mathrm{~nm}$, respectively. The mobile phase was a mixed liquid of water and acetonitrile containing $0.1 \%$ formic acid. 
Samples were injected in $2 \mu \mathrm{l}$ aliquots, and the flow rate was $0.4 \mathrm{ml} / \mathrm{min}$.

\section{Cell culture and cell viability test}

The RAW 264.7 cell line was obtained from the American Type Culture Collection (ATCC, Manassas, VA, USA) and maintained in Dulbecco's modified Eagle's medium (DMEM, Hyclone, Logan, UT, USA) containing 10\% fetal bovine serum (FBS, Hyclone) at $37{ }^{\circ} \mathrm{C}$ in a humidified atmosphere with $5 \% \mathrm{CO}_{2}$. For all experiments, LPS was used at a final concentration of $1 \mu \mathrm{g} / \mathrm{ml}$ after serum starvation for $12 \mathrm{~h}$. Various concentrations of PS + CR were added to the culture medium $1 \mathrm{~h}$ prior to the addition of LPS, and cells were treated for $24 \mathrm{~h}$. After treatment, viable cells were stained with 3-(4,5-dimethylthiazol)-2,5-diphenyltetrazolium bromide (MTT) and dissolved in DMSO. Absorbance was measured at $540 \mathrm{~nm}$ using a Tecan Infinite M200 PRO ELISA microplate reader (Tecan Group Ltd., Männedorf, Switzerland). Cell viability was defined relative to untreated controls by the equation: viability (\% control $)=100 \times($ absorbance of treated sample/absorbance of control).

\section{Determination of $\mathrm{NO}, \mathrm{PGE}_{2}$, and cytokines}

Concentrations of $\mathrm{NO}$ were monitored by measuring the nitrite content in the culture supernatant after mixing the culture media with Griess reagent (1\% sulphanilamide, $\quad 0.1 \% N$-1-naphthylenediamine dihydrochloride, and $2.5 \%$ phosphoric acid). The absorbance was measured at $540 \mathrm{~nm}$ after $10 \mathrm{~min}$ of incubation. The levels of $\mathrm{PGE}_{2}$ and pro-inflammatory cytokines TNF- $\alpha$, IL- $1 \beta$, and IL- 6 were assessed by enzyme-linked immunosorbent assay (ELISA) using anti-mouse $\mathrm{PGE}_{2}$, TNF- $\alpha$, IL- $1 \beta$, or IL- 6 antibodies and a biotinylated secondary antibody according to the manufacturer's instructions.

\section{Western blot analysis}

Cell extracts were prepared by lysing cells in RIPA Lysis Buffer (Thermo Fisher Scientific, Waltham, MA, USA). The nuclear fractions for the NF- $\mathrm{kB}$ analysis were set up using a commercial kit (Chemicon International, Inc., Billerica, MA, USA). Equal amounts of proteins were separated using sodium dodecyl sulfate polyacrylamide gel electrophoresis (SDS-PAGE) and transferred to a nitrocellulose membrane (Amersham Life Science, Arlington Heights, IL, USA). After blocking with TBS-T buffer [20 mM Tris (pH 7.4), $150 \mathrm{mM} \mathrm{NaCl}, 0.1 \%$ Tween 20] containing 5\% skim milk, the membranes were incubated with primary and secondary antibodies. The membranes were washed with TBS-T buffer and visualized with ECL Western blotting detection reagents (Amersham).

\section{Carrageenan-induced paw edema}

Sprague-Dawley rats (6-week-old males, 140-160 g) were provided by Samtako Bio (Osan, Korea), allowed to acclimate to their new environment for 1 week, and maintained in a clean room at the animal laboratory. The animals were caged with a supply of filtered pathogen-free air, a temperature between 20 and $23{ }^{\circ} \mathrm{C}$, a 12-h light:dark cycle, and a relative humidity of $50 \%$; they were fed standard rat chow (Purina, Korea) and water ad libitum. The rats were divided into five groups: normal; CA; CA + dexamethasone (DEXA, $1 \mathrm{mg} / \mathrm{kg}$ ) as a standard reference; CA + PS + CR $(0.3 \mathrm{~g} / \mathrm{kg})$; and $\mathrm{CA}+$ PS + CR $(1.0 \mathrm{~g} / \mathrm{kg}) . P S+C R$ and DEXA were dissolved in saline and orally administered to the control rats for 4 consecutive days. Paw edema was induced by injecting $0.1 \mathrm{ml}$ of $1 \% \mathrm{w} / v \mathrm{CA}$ suspended in saline into the subplantar tissues of the right hind paw of each rat. The volume of the paw was measured with a Plethysmometer (LE 7500; LETICA Scientific Instruments, Barcelona, Spain) immediately prior to CA injection and then again $1,2,3$, and $4 \mathrm{~h}$ after injection. After euthanasia with $\mathrm{CO}_{2}$, the paw samples were prepared.

\section{Immunohistochemistry}

The separated dorsum and ventrum pedis skin from the hind paws were fixed in 10\% neutral buffered formalin and then embedded in paraffin, sectioned, and stained with hematoxylin and eosin (HE) to determine general histopathological profiles. Next, changes in the immunoreactivities of cyclooxygenase-2 (COX-2), inducible nitric oxide synthase (iNOS), and TNF- $\alpha$ were observed with purified primary antibodies with avidin-biotinperoxidase $(A B C)$ and peroxidase substrate kits (Vector Labs, Burlingame, CA, USA). Briefly, the endogenous peroxidase activity was blocked by incubation in methanol and $0.3 \% \mathrm{H}_{2} \mathrm{O}_{2}$ for $30 \mathrm{~min}$, while non-specific binding of immunoglobulin was blocked with normal horse serum blocking solution for $1 \mathrm{~h}$ in a humidity chamber after heating $\left(95-100{ }^{\circ} \mathrm{C}\right)$ for epitope retrieval in $10 \mathrm{mM}$ citrate buffer $(\mathrm{pH} 6.0)$. The primary antisera were treated overnight at $4{ }^{\circ} \mathrm{C}$ in a humidity chamber and then incubated with biotinylated universal secondary antibody and $\mathrm{ABC}$ reagents for $1 \mathrm{~h}$ at room temperature in a humidity chamber. Finally, the sections were treated with a peroxidase substrate kit for $3 \mathrm{~min}$ at room temperature.

\section{Histomorphometry}

To observe the changes induced by CA either with or without PS + CR treatment in greater detail, the thicknesses of the dorsum and ventrum pedis skin (from the epidermis to the dermis; keratin layers were excluded) were measured as $\mu \mathrm{m} /$ paw with an automated image analyzer (iSolution FL ver 9.1, IMT i-Solution Inc., 
Vancouver, Canada) under $40 \mathrm{X}$ magnification microscopy (Model Eclipse 80i, Nikon, Tokyo, Japan). Using an automated image analyzer under $200 \mathrm{X}$ magnification, we also counted the number of infiltrated inflammatory cells in the dermis as cells $/ \mathrm{mm}^{2}$ of dermis. Additionally, the cells occupied by over $10 \%$ of COX-2 and iNOS immunoreactivities were regarded as positive. In the present study, the number of COX-2- and iNOS-positive cells were separately calculated in the epithelial lining (cells/100 epithelial cells) and in the dermis (cells $/ \mathrm{mm}^{2}$ of dermis) using a digital image analyzer. The histopathologist was blind to the group distribution when this analysis was carried out.

\section{Statistical analysis}

The experimental results are presented as the mean \pm standard deviation (S.D.) of experiments repeated at least three times. In each treatment group, statistical significance was compared and verified using one-way analysis of variance (ANOVA) or Student's $t$-test $(p<0.05$ or $p<$ 0.01 ). Additionally, the percentage point (pp) changes between normal and CA groups were calculated to monitor the severities of acute inflammation induced in this study; to assess efficacy, the pp. changes between CA and PS + CR- or DEXA-treated skin were also calculated as follows:

Percentage Point Changes compared with Normal (\%) $=(($ Data of CA - Data of Normal $) /$ Data of Normal $) \times 100$.

Percentage Point Changes compared with CA (\%) $=(($ Data of PS + CR-treated rats - Data of CA $) /$ Data of CA) $\times 100$.

\section{Results}

UPLC analysis of PS + CR

To evaluate the quantitative UPLC analysis of PS + CR, we used two standards for quality control based on the
Korean Pharmacopoeia and the Korean Food and Drug Administration. The contents of the two compounds were calculated from the calibration curves of the standards (Fig. 1). All standard peaks were identified within 4-8 min of retention time, and the following amounts of compound were detected: $0.149 \pm 0.004 \mathrm{ppm}$ for epicatechin and $37.29 \pm 0.11 \mathrm{ppm}$ for berberine.

\section{Effects of PS + CR on NO production and iNOS protein expression}

To confirm the anti-inflammatory effects of PS + CR, we investigated LPS-induced NO production in RAW 264.7 cells. The cells were treated with various concentrations (3-300 $\mu \mathrm{g} / \mathrm{ml})$ of PS + CR for $1 \mathrm{~h}$, followed by continuous incubation with LPS $(1 \mu \mathrm{g} / \mathrm{ml})$ for $24 \mathrm{~h}$; NO production was then measured using a Griess reagent. Treatment with $30-300 \mu \mathrm{g} / \mathrm{ml}$ PS + CR significantly inhibited the increased NO production induced by LPS (Fig. 2a, $p<0.01$ ). To evaluate the possibility that inhibition of NO production by PS+CR was associated with modulated expression of the iNOS protein as a key enzyme responsible for $\mathrm{NO}$ synthesis, we performed Western blot analysis. As expected, LPS significantly increased iNOS protein expression; however, pretreatment with PS+CR $(300 \mu \mathrm{g} / \mathrm{ml})$ significantly inhibited the increased iNOS expression induced by LPS (Fig. 2b, $p<0.01$ ). Furthermore, cell viability was not affected by co-treatment with LPS and PS $+C R$ (Fig. 2c). These results demonstrated that the inhibitory effect of PS+CR on LPS-stimulated NO production was not due to cytotoxic effects.

\section{Effects of $\mathrm{PS}+\mathrm{CR}$ on $\mathrm{PGE}_{2}$ production and COX-2 protein expression}

To investigate whether PS + CR inhibits production of $\mathrm{PGE}_{2}$ and expression of COX-2 as a potent mediator of
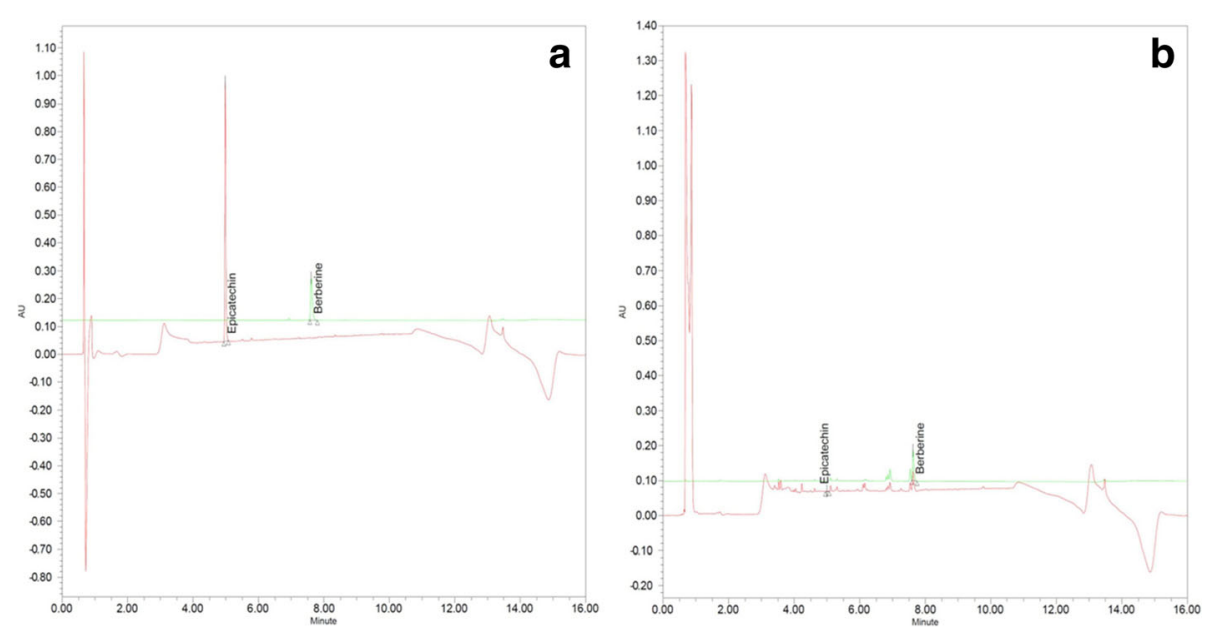

Fig. 1 Analysis of compounds in a mixture of Pelargonium sidoides and Coptis chinensis root (PS + CR) by ultra-performance liquid chromatography (UPLC). UPLC chromatograms of standard compounds; epicatechin: $230 \mathrm{~nm}$, berberine: $345 \mathrm{~nm}$. a standard compounds. b PS + CR extracts 

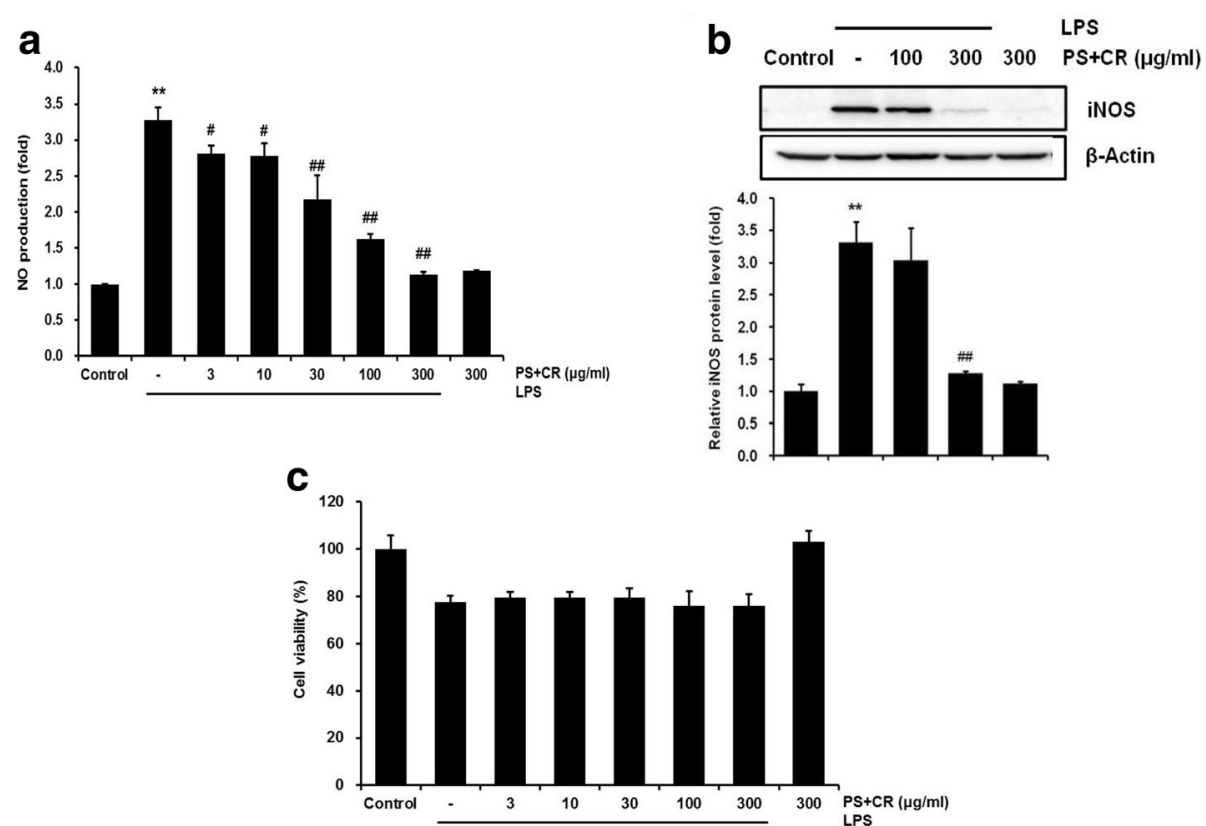

Fig. 2 Inhibition of nitric oxide (NO) production and inducible nitric oxide synthase (iNOS) expression by PS + CR. RAW 264.7 cells were treated with 3-300 $\mu \mathrm{g} / \mathrm{ml} \mathrm{PS}+$ CR for $1 \mathrm{~h}$ prior to the addition of lipopolysaccharide (LPS) $(1 \mu \mathrm{g} / \mathrm{ml})$ and further incubated for $24 \mathrm{~h}$. a Effects of PS + CR on NO production. Secreted nitrite concentrations in the culture medium were assayed using the Griess reagent method. $\mathbf{b}$ Effects of PS + CR on iNOS protein expression. Equal amounts of total protein $(50 \mu \mathrm{g})$ were separated by SDS-PAGE. $\beta$-Actin was used as a loading control, and the bar chart shows the quantitative evaluation of iNOS bands by densitometry. (c) Effects of PS + CR plus LPS on cell viability. Cell viability was measured by 3-(4,5-dimethylthiazol)-2,5-diphenyltetrazolium bromide (MTT) assay after $24 \mathrm{~h}$ of incubation. Values represent the mean \pm S.D. of three independent experiments (significant compared to the control, ${ }^{* *} p<0.01$; significant compared to LPS alone, ${ }^{\#} p<0.05$ or ${ }^{\# \#} p<0.01$ )

inflammation [21], we utilized ELISA and Western blot analysis, respectively. Treatment with LPS significantly increased production of $\mathrm{PGE}_{2}$; however, treatment with $\mathrm{PS}+\mathrm{CR}$ at concentrations of $30-300 \mu \mathrm{g} / \mathrm{ml}$ significantly suppressed this increased production (Fig. 3a, $p<0.01$ ).
Next, we evaluated the effects of PS+CR on COX-2 and found that PS+CR $(300 \mu \mathrm{g} / \mathrm{ml})$ significantly inhibited LPS-enhanced COX-2 expression (Fig. $3 \mathrm{~b}, p<0.01$ ). These results suggest that $\mathrm{PS}+\mathrm{CR}$ may inhibit $\mathrm{PGE}_{2}$ synthesis by regulating expression of COX-2.

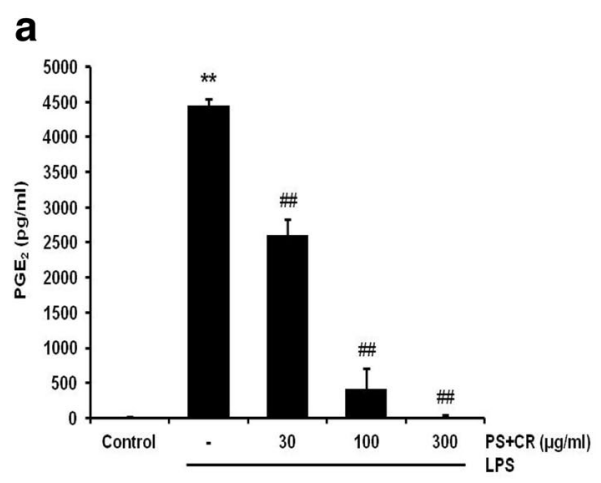

\section{b}
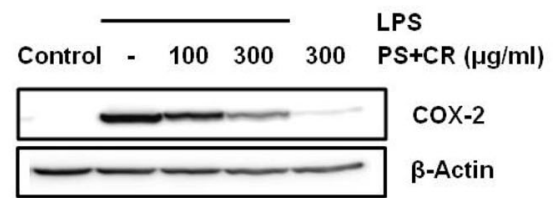

$\operatorname{cox}-2$

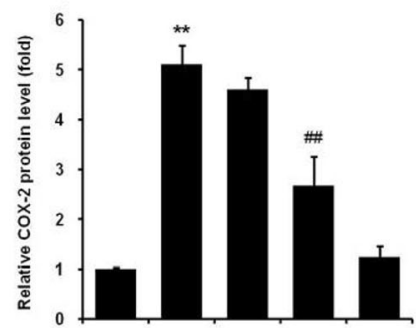

Fig. 3 Inhibition of the LPS-induced prostaglandin $E_{2}\left(P G E_{2}\right)$ secretion and cyclooxygenase-2 (COX-2) expression by PS + CR. RAW 264.7 cells were treated with $30-300 \mu \mathrm{g} / \mathrm{ml}$ of PS + CR for $1 \mathrm{~h}$ prior to the addition of LPS $(1 \mu \mathrm{g} / \mathrm{ml})$ and further incubated for $24 \mathrm{~h}$. a Effects of PS + CR on the levels of $\mathrm{PGE}_{2}$. $\mathrm{PGE}_{2}$ concentrations in the culture medium were assayed using the $\mathrm{PGE} \mathrm{E}_{2}$ ELISA kit as detailed in the Methods section. $\mathbf{b}$ Effects of PS + CR on COX-2 protein expression. Equal amounts of total protein $(50 \mu \mathrm{g})$ were separated by SDS-PAGE. $\beta$-Actin was used as a loading control, and the bar chart shows the quantitative evaluation of COX-2 bands by densitometry. Values represent the mean \pm S.D. of three independent experiments (significant compared to the control, ${ }^{* *} p<0.01$; significant compared to LPS alone, ${ }^{\# \#} p<0.01$ ) 


\section{Effects of PS + CR on production of pro-inflammatory cytokines}

We used ELISAs to evaluate whether PS + CR reduces the production of pro-inflammatory cytokines TNF- $\alpha$, IL-1 $\beta$, and IL-6. Treatment with LPS significantly increased production of TNF- $\alpha$, IL-1 $\beta$, and IL- 6 , but these increases were significantly reduced by treatment with 30-300 $\mu \mathrm{g} / \mathrm{ml}$ PS + CR (Fig. 4a-c, $p<0.01$ ).

\section{Effects of PS + CR on NF-KB signaling pathway}

$\mathrm{NF}-\mathrm{KB}$ is a key transcription factor with important roles in a wide range of biological effects, including inflammation [22]. To examine whether PS $+\mathrm{CR}$ regulates $\mathrm{NF}-\mathrm{kB}$ nuclear translocation as well as $\mathrm{I}-\mathrm{kB} \alpha$ phosphorylation and degradation, we performed Western blot analysis. As expected, LPS treatment increased phosphorylated $\mathrm{I}-\mathrm{k} \mathrm{B} \alpha(\mathrm{p}-\mathrm{I}-\mathrm{k} \mathrm{B} \alpha)$ protein expression and decreased total $\mathrm{I}-\kappa \mathrm{B} \alpha$ protein expression (Fig. $5 \mathrm{a}, \mathrm{b}$ ). However, pretreatment with $300 \mu \mathrm{g} / \mathrm{ml}$ PS + CR significantly decreased the phosphorylation of I- $\kappa \mathrm{B} \alpha$ and blocked the LPS-induced degradation of I-kB $\alpha$ (Fig. $5 \mathrm{a}, \mathrm{b} ; p<0.01$ ), suggesting that $\mathrm{PS}+\mathrm{CR}$ may regulate phosphorylation of $\mathrm{I}-\mathrm{kB} \alpha$ and I$\kappa \mathrm{B} \alpha$ expression. Furthermore, the accumulation of NF$\mathrm{\kappa B}$ in nuclear fractions following LPS treatment was significantly and dose-dependently reduced by PS + CR pretreatment (Fig. 5c, $p<0.05$ for $100 \mu \mathrm{g} / \mathrm{ml} ; p<0.01$ for $300 \mu \mathrm{g} / \mathrm{ml})$. These results indicate that PS + CR inhibits NF- $\mathrm{KB}$ activation by inhibiting $\mathrm{I}-\mathrm{\kappa} \mathrm{B} \alpha$ degradation and the nuclear translocation of NF- $\mathrm{kB}$.

\section{Effects of PS + CR on CA-induced paw edema}

To determine the anti-inflammatory effects of PS $+\mathrm{CR}$, we used a CA-induced paw edema method as an in vivo model of acute inflammation. The inhibition of paw edema formation by PS + CR was calculated by comparing the hind paw volumes of rats treated with this combination with those of CA-treated rats. Additionally, DEXA (1 $\mathrm{mg} / \mathrm{kg}$ ) was used as a positive control. As shown in Fig. 6, DEXA and PS + CR (0.3 and $1.0 \mathrm{~g} / \mathrm{kg})$ significantly inhibited paw edema $(p<0.01$ for DEXA, $p$ $<0.05$ or $p<0.01$ for $1.0 \mathrm{~g} / \mathrm{kg}$ PS $+\mathrm{CR})$.

\section{Histopathological evaluation of PS + CR in CA-induced acute inflammation}

The histological profiles, including mast cell stains, of the effects of PS $+\mathrm{CR}$ treatment on the dorsum and ventrum pedis skin are shown in Fig. 7. Additionally, the representative immunohistochemical profiles of the epithelial and dermal COX-2, iNOS, and TNF- $\alpha$ immunolabeled cells in the dorsum and ventrum pedis skin tissues are shown in Fig. 8. The histomorphometrical measurements of the dorsum pedis and ventrum pedis skin are also listed in Tables 1 and 2, respectively.

Marked and significant $(p<0.01)$ increases in the thickness of the dorsum and ventrum pedis skin resulted from CA-induced acute edematous inflammation in CA-treated rats compared with normal rat paw skin. The dorsum and ventrum pedis cutaneous regions in CA-treated rats also displayed significant $(p<0.01)$
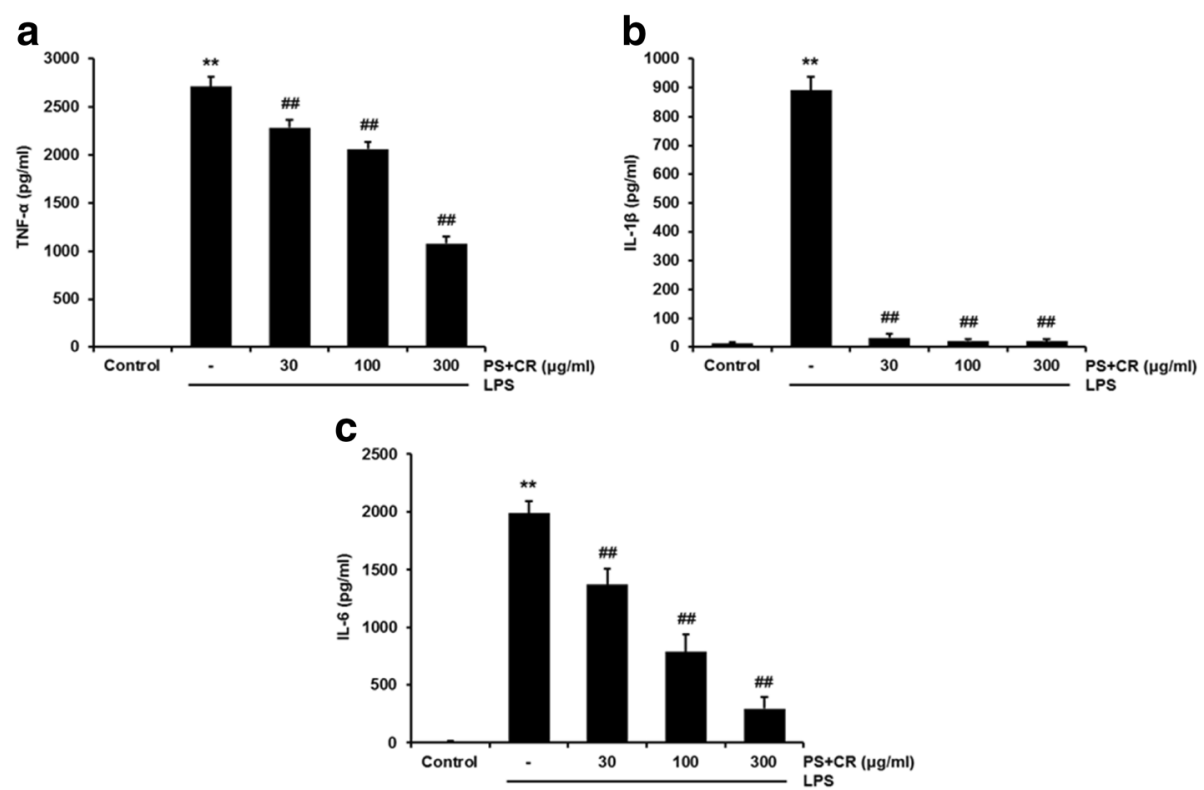

Fig. 4 Inhibition of the LPS-induced secretion of pro-inflammatory cytokines by PS + CR. RAW 264.7 cells were treated with 30-300 $\mu \mathrm{g} / \mathrm{ml}$ of PS + CR for $1 \mathrm{~h}$ prior to the addition of LPS $(1 \mu \mathrm{g} / \mathrm{ml})$ and further incubated for $24 \mathrm{~h}$. Levels of TNF-a (a) IL-1 $\beta$ (b) and IL-6 (c). As detailed in the Methods section, the concentrations of cytokines in the culture medium were assayed using a kit. Values represent the mean \pm S.D. of three independent experiments (significant compared to the control, ${ }^{* *} p<0.01$; significant compared to LPS alone, ${ }^{\# \#} p<0.01$ ) 


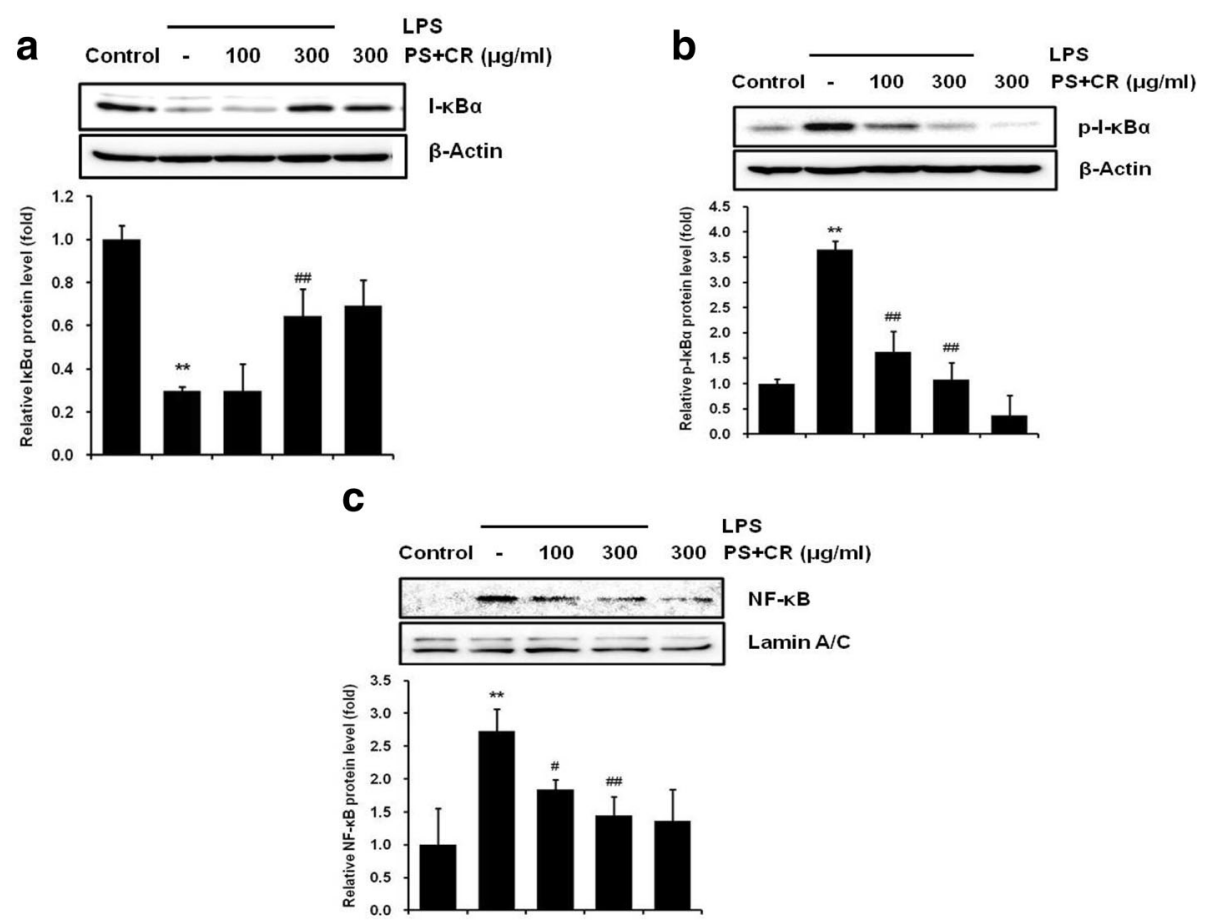

Fig. 5 Inhibition of LPS-induced nuclear factor-kappa B (NF-kB) protein expression by PS + CR. (a, b) Levels of I-kBa and phospho-l-kBa. RAW 264.7 cells were treated with 100 and $300 \mu \mathrm{g} / \mathrm{ml}$ of PS + CR for $1 \mathrm{~h}$ prior to the addition of lipopolysaccharide (LPS) (1 $\mathrm{\mu g} / \mathrm{ml})$ and further incubated for $30 \mathrm{~min}$. Cytosol fraction proteins were separated by SDS-PAGE. $\beta$-Actin was used as a loading control, and the bar chart shows the quantitative evaluation of I-KBa and phospho-I-KBa bands by densitometry. (c) The levels of NF-KB. RAW 264.7 cells were treated with 100 and $300 \mu \mathrm{g} / \mathrm{ml}$ of PS + CR for $1 \mathrm{~h}$ prior to the addition of LPS $(1 \mu \mathrm{g} / \mathrm{ml})$ and further incubated for $1 \mathrm{~h}$. Nuclear fraction proteins were separated by SDS-PAGE. Lamin A/C was used as a loading control, and the bar chart shows the quantitative evaluation of NF-KB bands by densitometry. Values represent the mean \pm S.D. of three independent experiments (significant compared to the control; ${ }^{* *} p<0.01$, significant compared to LPS alone, ${ }^{\#} p<0.05$ or ${ }^{\# \#} p<0.01$ )

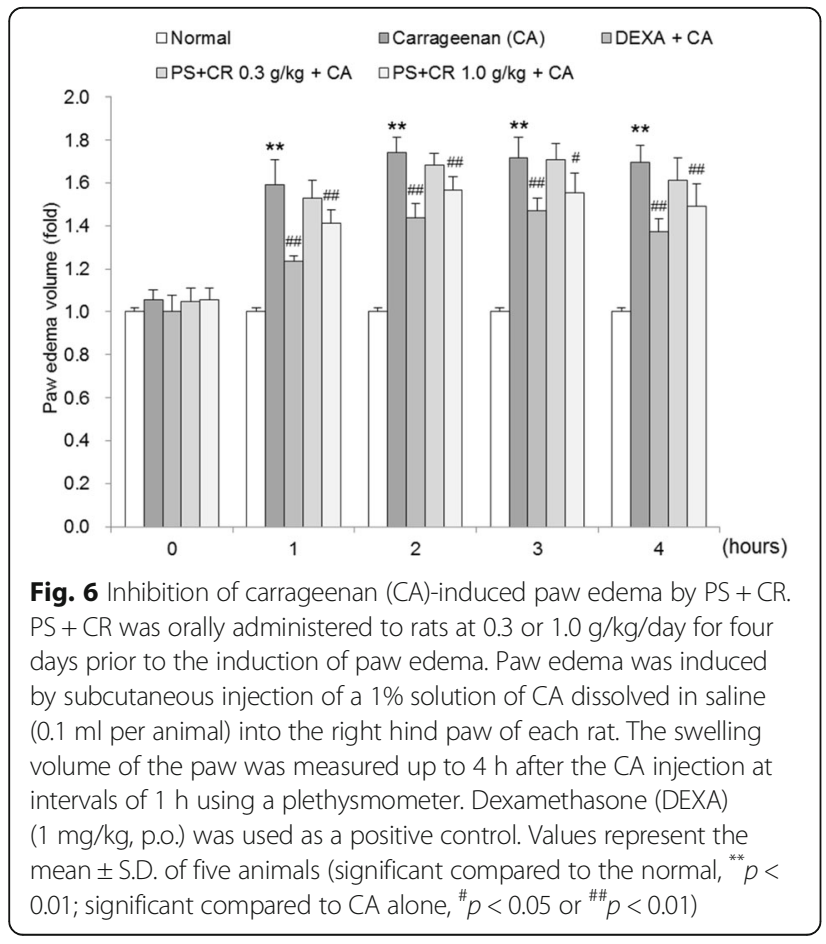

degranulation-related decreases in mast cell numbers; increases in infiltrated inflammatory cells; and increased epithelial and dermal COX-2-, iNOS-, and TNF- $\alpha-$ positive cells compared to control rat paw skin. However, the CA-induced acute edematous inflammatory changes were significantly $(p<0.01$ or $p<0.05)$ and dose-dependently inhibited by treatment with 0.3 and $1.0 \mathrm{~g} / \mathrm{kg}$ PS $+\mathrm{CR}$, as well as by treatment with DEXA. According to histopathological observations, PS + CR treatment $(1.0 \mathrm{~g} / \mathrm{kg})$ had a somewhat less pronounced anti-inflammatory effect than DEXA treatment on CA-induced acute inflamed hind paws (Tables 1 and 2; Figs. 7 and 8).

The thicknesses of dorsum pedis and ventrum pedis skin in CA-treated rats were changed by 147.96 and 200.68 pp., respectively, compared with normal controls. The pp. changes in the thickness of dorsum pedis skin in rats treated with DEXA, 0.3 and $1.0 \mathrm{~g} / \mathrm{kg}$ PS + CR were $-48.71,-26.29$, and $-35.58 \%$, respectively, compared with CA-treated rats, and they were $-53.98,-22.39$, and $-45.08 \%$, respectively, in ventrum pedis skin compared with CA-treated rats. Additionally, the numbers of infiltrated inflammatory cells in the dorsum pedis and ventrum pedis skin in CA-treated rats were increased by 


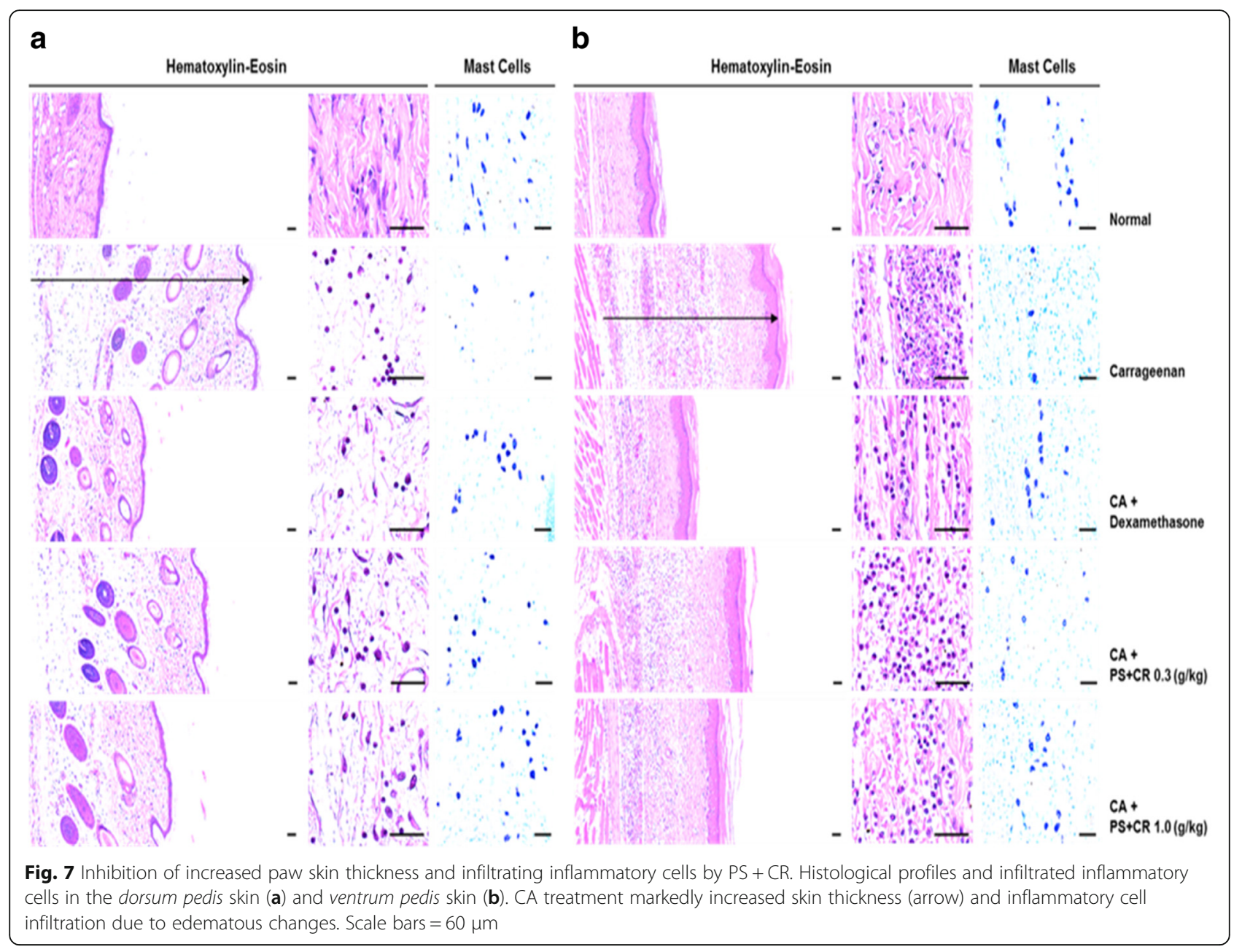

806.02 and 4820.21 pp., respectively, compared with normal controls. In rats treated with DEXA, 0.3 and $1.0 \mathrm{~g} / \mathrm{kg}$ PS + CR, the pp. changes in the numbers of infiltrated inflammatory cells were $-77.53,-34.31$, and $-57.11 \%$, respectively, in dorsum pedis skin, and they were -70.89 , -38.52 , and $-57.45 \%$, respectively, in ventrum pedis skin compared with CA-treated rats.

The numbers of mast cells in the dorsum pedis and ventrum pedis skin in CA-treated rats were changed by -75.66 and -91.18 pp., respectively, compared with normal controls. In rats treated with DEXA, 0.3 and $1.0 \mathrm{~g} / \mathrm{kg}$ PS $+\mathrm{CR}$, the pp. changes in numbers of mast cells were $237.27,118.18$, and $191.82 \%$, respectively, in dorsum pedis skin, and they were $702.78,305.56$, and $580.56 \%$, respectively, in ventrum pedis skin compared with CA-treated rats. The numbers of epithelial COX-2immunoreactive cells in the dorsum pedis and ventrum pedis skin in CA-treated rats were changed by 2055.56 and 1673.68 pp., respectively, compared with normal controls. In rats treated with DEXA, 0.3 and $1.0 \mathrm{~g} / \mathrm{kg}$ PS $+\mathrm{CR}$, the pp. changes in the numbers of COX-2immunoreactive cells were $-64.18,-23.20$, and -
$53.61 \%$, respectively, in the epithelial dorsum pedis skin, and they were $-64.39,-21.36$ and $-41.54 \%$, respectively, in epithelial ventrum pedis skin compared with CA-treated rats. Additionally, the numbers of dermal COX-2-immunoreactive cells in the dorsum pedis and ventrum pedis skin in CA-treated rats were changed by 1112.12 and 2364.07 pp., respectively, compared with normal controls. In rats treated with DEXA, 0.3 and $1.0 \mathrm{~g} / \mathrm{kg}$ $\mathrm{PS}+\mathrm{CR}$, the pp. changes in numbers of COX-2immunoreactive cells were $-75.75,-35.13$, and $-64.88 \%$, respectively, in the dermal dorsum pedis skin, and they were $-82.24,-42.11$, and $-62.41 \%$, respectively, in dermal ventrum pedis skin compared with CA-treated rats.

The numbers of epithelial iNOS-immunoreactive cells in the dorsum pedis and ventrum pedis skin in CAtreated rats were changed by 1872.73 and 370.15 pp., respectively, compared with normal controls. In rats treated with DEXA, 0.3 and $1.0 \mathrm{~g} / \mathrm{kg}$ PS + CR, the pp. changes in numbers of epithelial iNOS-immunoreactive cells were $-59.68,-14.98$, and $-35.02 \%$, respectively, in dorsum pedis skin, and they were $-62.86,-24.76$, and $-43.81 \%$, respectively, in ventrum pedis skin compared 


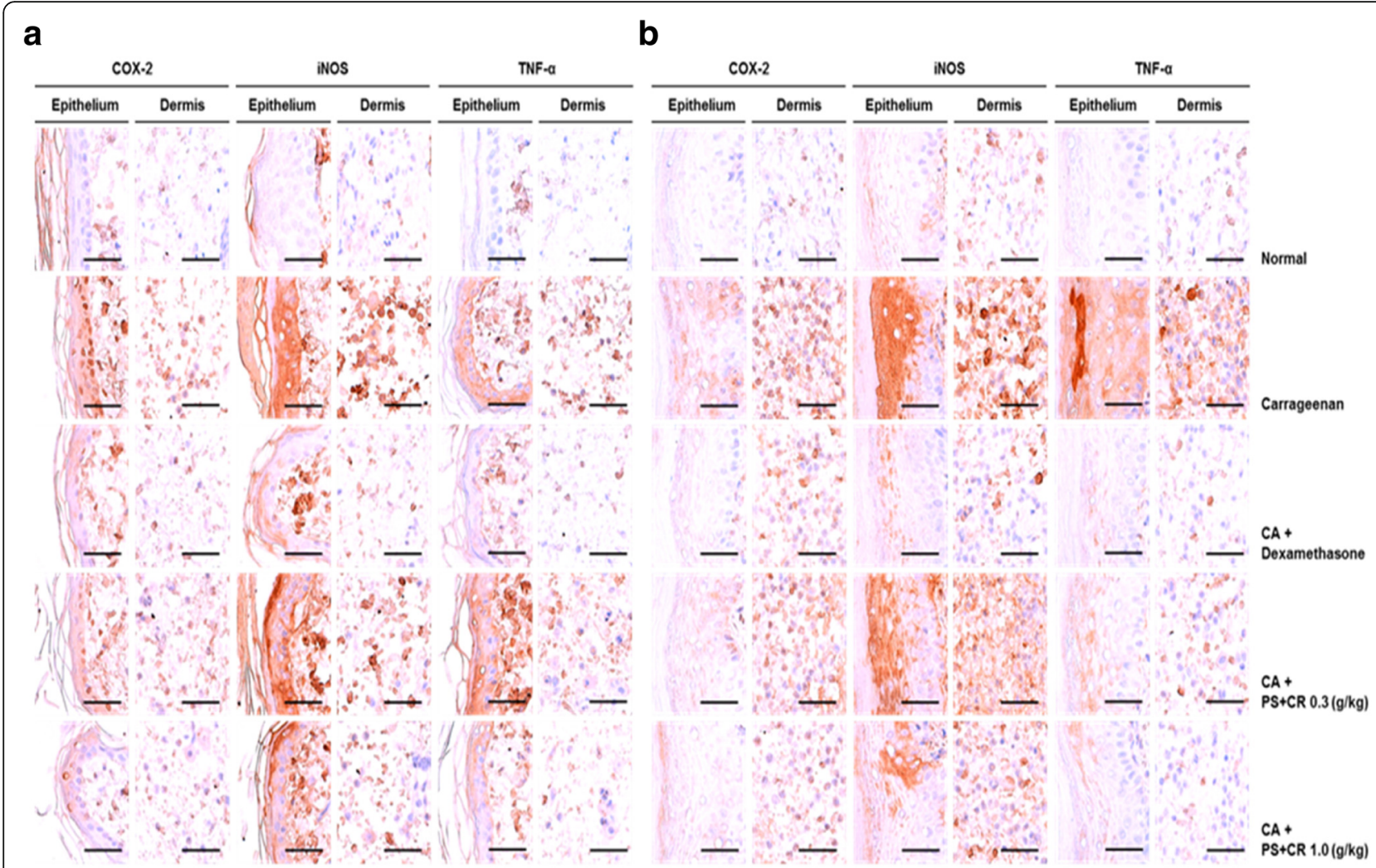

Fig. 8 Representative immunohistochemical profiles of COX-2, iNOS, and TNF-a in paw skin. Marked increases of COX-2, iNOS, and TNF-a-positive cells were detected in the epithelium and dermis of the dorsum (a) and ventrum pedis skin tissues (b) in CA-treated rats compared with normal rats. Scale bars $=60 \mu \mathrm{m}$

with CA-treated rats. Moreover, the numbers of dermal iNOS-immunoreactive cells in the dorsum pedis and ventrum pedis skin in CA-treated rats were changed by 1940.86 and 2534.06 pp., respectively, compared with normal controls. In rats treated with DEXA, 0.3 and $1.0 \mathrm{~g} / \mathrm{kg}$ PS $+\mathrm{CR}$, the pp. changes in the numbers of dermal iNOSimmunoreactive cells were $-79.24,-42.99$, and $-71.29 \%$, respectively, in dorsum pedis skin, and they were - 79.94, 33.29 , and $-53.51 \%$, respectively, in ventrum pedis skin compared with CA-treated rats.
The numbers of epithelial TNF- $\alpha$-immunoreactive cells in the dorsum pedis and ventrum pedis skin in CAtreated rats were changed by 8620.00 and $1476.92 \mathrm{pp}$., respectively, compared with normal controls. In rats treated with DEXA, 0.3 and $1.0 \mathrm{~g} / \mathrm{kg}$ PS + CR, the pp. changes in the numbers of epithelial TNF- $\alpha$ immunoreactive cells were $-86.93,-18.81$, and $52.52 \%$, respectively, in dorsum pedis skin, and they were $-59.76,-31.22$, and $-50.73 \%$, respectively, in ventrum pedis skin compared with CA-treated rats. Furthermore,

Table 1 Changes on the histomorphometrical analysis of hind paw skins

\begin{tabular}{|c|c|c|c|c|}
\hline \multirow[t]{2}{*}{ Regions Index Groups } & \multicolumn{2}{|l|}{ Dorsum pedis skin } & \multicolumn{2}{|l|}{ Ventrum pedis skin } \\
\hline & $\begin{array}{l}\text { Thickness (epidermis } \\
\text { to dermis; } \mu \mathrm{m} \text { ) }\end{array}$ & $\begin{array}{l}\text { Infiltrated inflammatory cells } \\
\text { (cells } / \mathrm{mm}^{2} \text { of dermis) }\end{array}$ & $\begin{array}{l}\text { Thickness (epidermis } \\
\text { to dermis; } \mu \mathrm{m} \text { ) }\end{array}$ & $\begin{array}{l}\text { Infiltrated inflammatory cells } \\
\text { (cells } / \mathrm{mm}^{2} \text { of dermis) }\end{array}$ \\
\hline Normal & $554.49 \pm 45.78$ & $33.20 \pm 6.98$ & $367.00 \pm 47.70$ & $38.60 \pm 5.81$ \\
\hline Carrageenan (CA) & $1374.91 \pm 133.42^{a}$ & $300.80 \pm 48.15^{a}$ & $1103.50 \pm 163.77^{d}$ & $1899.20 \pm 240.07^{d}$ \\
\hline CA + Dexamethasone & $705.25 \pm 69.63^{b c}$ & $67.60 \pm 19.51^{c}$ & $507.85 \pm 70.23^{\mathrm{ef}}$ & $552.80 \pm 111.52^{d f}$ \\
\hline$C A+P S+C R 0.3(g / k g)$ & $1013.45 \pm 89.90^{a c}$ & $197.60 \pm 20.72^{\mathrm{ac}}$ & $856.48 \pm 83.57^{\mathrm{df}}$ & $1167.60 \pm 213.76^{d f}$ \\
\hline$C A+P S+C R 1.0(\mathrm{~g} / \mathrm{kg})$ & $885.66 \pm 85.71^{\mathrm{ac}}$ & $129.00 \pm 41.48^{\mathrm{ac}}$ & $605.99 \pm 42.23^{d f}$ & $808.20 \pm 178.40^{d f}$ \\
\hline
\end{tabular}


Table 2 Changes on the mast cells, COX-2-, iNOS- and TNF-a-immunoreactive cells in the hind paw skins

\begin{tabular}{|c|c|c|c|c|c|}
\hline \multirow{2}{*}{$\frac{\text { Regions/Cells }}{\text { Dorsum pedis skin }}$} & \multicolumn{2}{|c|}{ Normal Carrageenan (CA) } & \multirow[t]{2}{*}{ CA + Dexamethasone } & \multirow[t]{2}{*}{$C A+P S+C R 0.3(\mathrm{~g} / \mathrm{kg})$} & \multirow[t]{2}{*}{$C A+P S+C R 1.0(\mathrm{~g} / \mathrm{kg})$} \\
\hline & & & & & \\
\hline \multicolumn{6}{|c|}{ Epidermis (cells/100 epithelial cells) } \\
\hline coX-2 + cells & $3.60 \pm 2.61$ & $77.60 \pm 5.94^{d}$ & $27.80 \pm 10.57^{\text {de }}$ & $59.60 \pm 9.71^{\mathrm{df}}$ & $36.00 \pm 6.52^{\text {de }}$ \\
\hline iNOS + cells & $4.40 \pm 2.30$ & $86.80 \pm 5.81^{\mathrm{a}}$ & $35.00 \pm 7.52^{\mathrm{ac}}$ & $73.80 \pm 4.32^{\mathrm{ac}}$ & $56.40 \pm 8.41^{\mathrm{ac}}$ \\
\hline TNF-a + cells & $1.00 \pm 0.71$ & $87.20 \pm 6.06^{a}$ & $11.40 \pm 4.10^{\mathrm{bc}}$ & $70.80 \pm 7.46^{\mathrm{ac}}$ & $41.40 \pm 7.40^{\mathrm{ac}}$ \\
\hline \multicolumn{6}{|c|}{ Dermis (cells $/ \mathrm{mm}^{2}$ of dermis) } \\
\hline Mast cells & $90.40 \pm 15.63$ & $22.00 \pm 7.52^{a}$ & $74.20 \pm 4.44^{b c}$ & $48.00 \pm 13.36^{\mathrm{ac}}$ & $64.20 \pm 13.59^{\mathrm{ac}}$ \\
\hline coX-2 + cells & $13.20 \pm 6.57$ & $160.00 \pm 31.34^{d}$ & $38.80 \pm 10.55^{\text {de }}$ & $103.80 \pm 9.86^{\text {de }}$ & $56.20 \pm 18.39^{\mathrm{de}}$ \\
\hline iNOS + cells & $18.60 \pm 2.41$ & $379.60 \pm 81.04^{d}$ & $78.80 \pm 12.13^{\mathrm{de}}$ & $216.40 \pm 71.14^{\mathrm{df}}$ & $109.00 \pm 54.16^{\mathrm{de}}$ \\
\hline TNF-a + cells & $10.20 \pm 1.92$ & $175.80 \pm 21.31^{a}$ & $47.60 \pm 12.93^{\mathrm{ac}}$ & $112.20 \pm 25.41^{a c}$ & $72.20 \pm 17.67^{\mathrm{ac}}$ \\
\hline \multicolumn{6}{|l|}{ Ventrum pedis skin } \\
\hline \multicolumn{6}{|c|}{ Epidermis (cells/100 epithelial cells) } \\
\hline cox-2 + cells & $3.80 \pm 1.70$ & $67.40 \pm 4.51^{\mathrm{a}}$ & $24.00 \pm 7.91^{\mathrm{ac}}$ & $53.00 \pm 7.18^{\mathrm{ac}}$ & $39.40 \pm 4.67^{\mathrm{ac}}$ \\
\hline iNOS + cells & $13.40 \pm 3.58$ & $63.00 \pm 6.52^{a}$ & $23.40 \pm 6.19^{b c}$ & $47.40 \pm 6.58^{\mathrm{ac}}$ & $35.40 \pm 5.13^{\mathrm{ac}}$ \\
\hline TNF-a + cells & $5.20 \pm 2.39$ & $82.00 \pm 10.89^{a}$ & $33.00 \pm 11.58^{\mathrm{ac}}$ & $56.40 \pm 6.23^{\mathrm{ac}}$ & $40.40 \pm 12.60^{\mathrm{ac}}$ \\
\hline \multicolumn{6}{|c|}{ Dermis (cells $/ \mathrm{mm}^{2}$ of dermis) } \\
\hline Mast cells & $81.60 \pm 10.90$ & $7.20 \pm 3.35^{\mathrm{a}}$ & $57.80 \pm 8.01^{\mathrm{ac}}$ & $29.20 \pm 7.19^{\mathrm{ac}}$ & $49.00 \pm 10.72^{\mathrm{ac}}$ \\
\hline coX $-2+$ cells & $33.40 \pm 11.61$ & $823.00 \pm 104.48^{\mathrm{a}}$ & $146.20 \pm 88.37^{\mathrm{bc}}$ & $476.40 \pm 98.22^{\mathrm{ac}}$ & $309.40 \pm 79.63^{\mathrm{ac}}$ \\
\hline iNOS + cells & $27.60 \pm 10.62$ & $727.00 \pm 102.27^{\mathrm{a}}$ & $145.80 \pm 50.93^{b c}$ & $485.00 \pm 88.26^{\mathrm{ac}}$ & $338.00 \pm 54.35^{\mathrm{ac}}$ \\
\hline TNF-a + cells & $19.20 \pm 4.60$ & $794.20 \pm 110.87^{d}$ & $57.20 \pm 17.48^{\mathrm{de}}$ & $308.00 \pm 56.57^{\mathrm{de}}$ & $144.00 \pm 40.35^{\mathrm{de}}$ \\
\hline
\end{tabular}

Values are expressed as mean \pm S.D. of five rat hind paws

${ }^{\mathrm{a}} p<0.01$ and ${ }^{\mathrm{b}} p<0.05$ as compared with normal by LSD test. ${ }^{c} p<0.01$ as compared with CA by LSD test

${ }^{d} p<0.01$ as compared with normal by MW test. ${ }^{e} p<0.01$ and ${ }^{f} p<0.05$ as compared with CA by MW test

the numbers of dermal TNF- $\alpha$-immunoreactive cells in the dorsum pedis and ventrum pedis skin in CA-treated rats were changed by 1623.53 and 4036.46 pp., respectively, compared with normal controls. In rats treated with DEXA, 0.3 and $1.0 \mathrm{~g} / \mathrm{kg} \mathrm{PS}+\mathrm{CR}$, the pp. changes in the numbers of dermal TNF- $\alpha$-immunoreactive cells were $-72.92,-36.18$, and $-58.93 \%$, respectively, in dorsum pedis skin, and they were $-92.80,-61.22$, and - $81.87 \%$, respectively, in ventrum pedis skin compared with CA-treated rats.

\section{Discussion}

In traditional medicine, different herbs are often mixed together to reduce toxicity and enhance efficacy [23]. Recent studies have reported that a mixture of $P$. sidoides and C. chinensis (PS + CR) has anti-oxidant, anti-cancer, and anti-inflammatory effects in diverse diseases [24, 25], however, the exact mechanisms of them remain to be elucidated. Here, we investigated the antiinflammatory effects of PS + CR using two kinds of model: cells treated with LPS to mimic the inflammatory process to study the effects of drugs and their molecular mechanisms, and animals stimulated with carrageenan to induce an inflammatory response in the paw. In this study, we showed that PS $+\mathrm{CR}$ has strong anti-inflammatory effects in vitro and in vivo, and its action is mediated through regulating inflammation marker proteins as well as transcription factors in RAW 264.7 cells.

Several researchers have attempted to inhibit activated macrophages as a potential therapy for inflammatory disease [1, 26]. Many studies have shown that activating macrophages with bacterial endotoxins, such as LPS, primarily triggers the production of inflammatory mediators, including $\mathrm{NO}$ and $\mathrm{PGE}_{2}$, as well as the inducible enzymes iNOS and COX-2 [27-29]. iNOS is the primary regulator of NO production and a target of inflammation-associated tissue damage and attenuation of iNOS-mediated NO production [30]. COX-2 is known as the key enzyme in the synthesis of prostaglandins and is a mediator of inflammation, angiogenesis, and cancer progression [21, 31]. Furthermore, COX-2 has been used as a therapeutic target in inflammatory disease, with advantageous anti-inflammatory effects [32, 33]. Inhibiting iNOS and $\mathrm{PGE}_{2}$ synthesis can relieve chronic inflammation induced by LPS [3, 34, 35]. We observed that the significant increases in iNOS and COX-2 expression and the excessive production of $\mathrm{NO}$ and $\mathrm{PGE}_{2}$ induced by LPS were attenuated in the presence of PS + CR. These findings indicate that PS + CR may have a therapeutic effect by treating inflammatory symptoms and pathogenic pain. 
Cytokines are related to the inflammation process in the human body. They are released by various inflammatory cells, including macrophages $[23,36]$. TNF- $\alpha$ is the most important cytokine in inflammation and has a crucial function in cellular and tissue damage [37, 38]. IL-1 $\beta$ has an important role in the processes underpinning swelling, heating, and redness [39]. As a mediator of the inflammatory process, IL-6 is released primarily by macrophages [40]. In this study, PS + CR inhibited the LPS-induced production of the pro-inflammatory cytokines TNF- $\alpha$, IL-1 $\beta$, and IL-6 $[37,38]$. Although PS + $\mathrm{CR}$ significantly inhibited three kinds of cytokine, it was more effective against the production of IL- $1 \beta$ than TNF- $\alpha$ or IL- 6 . Further investigation is needed to determine the different effects of PS + CR on the inhibition of inflammatory cytokines.

$\mathrm{NF}-\mathrm{kB}$ is an important transcription factor of inflammatory molecules [22]. NF- $\mathrm{BB}$ is a functional transcription factor that regulates the expression of genes involved in programmed cell death, inflammation, and survival. Several studies have shown that NF-kB plays critical roles in regulating various pro-inflammatory enzymes and cytokines, such as iNOS, COX-2, TNF- $\alpha$, IL-1 $\beta$ and IL-6 $[24,25]$. Under normal conditions, NF$\mathrm{kB}$ is located in the cytosol coupled with $\mathrm{I}-\mathrm{kB} \alpha$, its inhibitory molecule. However, during an activation process such as inflammation, $\mathrm{I}-\kappa \mathrm{B} \alpha$ is phosphorylated and degraded, and NF- $\mathrm{kB}$ moves to the nucleus by separating from $\mathrm{I}-\mathrm{k} \mathrm{B} \alpha[41,42]$. In this study, LPS induced significant phosphorylation of $\mathrm{I}-\kappa \mathrm{B} \alpha$ and nuclear translocation of NF-kB. Treatment with PS + CR significantly blocked the induction of the NF- $\mathrm{B}$ signaling pathway by LPS. These results suggest that PS + CR may modulate the NF- $\mathrm{kB}$ signaling pathway in the process of inflammation.

Loosening of inflammatory cell infiltration and connective tissues was observed around CA-treated sites $[43,44]$. In the present study, obvious increases in infiltrated inflammatory cells and increases in the skin thickness of both the ventrum and dorsum pedis were detected in CA-treated compared with control rat paws. However, these CA-induced acute inflammatory changes were significantly and dose-dependently reduced by treatment with two different doses of PS + CR ( 0.3 and $1.0 \mathrm{~g} / \mathrm{kg}$ ) and also by treatment with DEXA. These findings are considered direct evidence that PS + CR has favorable anti-inflammatory activities. The antiinflammatory effects of PS + CR $(1.0 \mathrm{~g} / \mathrm{kg})$ on the CAinduced edematous inflammatory skin changes were somewhat less pronounced than those of DEXA.

An obvious extension of mast cell degranulation in various dermal tissues has been observed in CA-induced acute inflammation, and inhibition of the mast cell degranulation has been used as an index of the efficacy of anti-inflammatory drugs [44-46]. In the present study, PS + CR markedly and dose-dependently inhibited mast cell degranulation and preserved the mast cell numbers in the dermis of CA-treated rats; mast cell degranulation was also significantly inhibited by treatment with DEXA in both dorsum pedis and ventrum pedis skin tissues. These results are considered direct evidence that PS + CR showed anti-inflammatory effects by at least partially controlling mast cell activation and degranulation.

Decreases in COX-2 immunoreactivity have been used as a valuable predictor of the favorable effects of test materials on inflammation [32, 33]. Additionally, iNOS is involved in the development of inflammation soon after CA administration, and NO produced by iNOS is related to the maintenance of the inflammatory response at later times [47]. TNF- $\alpha$ is involved in the pathogenesis of CA-induced inflammation [48]. In the present study, obvious increases in epithelial and dermal COX-2-, iNOS-, and TNF- $\alpha$-immunoreactive cells were detected on the dorsum pedis and ventrum pedis skin in CAtreated rats compared to control rats. However, these increases in inflammatory mediator-immunolabeled cells were significantly and dose-dependently decreased by treatment with two different doses of PS + CR as well as by DEXA. Therefore, we concluded that, under these experimental conditions, PS + CR has an at least partial and favorable inhibitory effect on acute inflammation and that this effect involves inflammatory mediators (COX-2, iNOS, and TNF- $\alpha$ ).

The results of chromatographic analysis showed that epicatechin and berberine are the two main markers of PS + CR. Treatment with epicatechin $(0.1-1 \mathrm{mM})$ was found to inhibit the production of nitrite (a nitric oxide metabolite) in the rat $\beta$-cell line RINm5F and this compound was shown to block the IL- $1 \beta$-induced expression of iNOS by inhibiting the nuclear localization of the p65 subunit of NF-kB [49]. In addition, Vasconcelos et al. [50] reported that treatment with epicatechin improved acute intestinal inflammatory disease. Furthermore, epicatechin exerted anti-inflammatory effects on diet-induced human Creactive protein and $\mathrm{NF}-\mathrm{kB}$ in vivo [51]. Berberine is an anti-inflammatory natural compound and is revealed to suppress hepatocyte inflammatory responses [52]. In addition, Guo et al. [53] suggested that berberine ameliorates obesity-associated liver and adipose tissue inflammation without altering AMPK phosphorylation. Furthermore, berberine suppresses the expression of acute phase proteins as well as proinflammatory cytokines, such as iNOS, COX-2, C-reaction protein, IL- $1 \beta$, IL-6, and TNF- $\alpha$ and it inhibits inflammation via diverse mechanisms, such as the AMPK, NF- $k B$, and MAPK signaling pathways [54-56]. Therefore, we suggest that the anti-inflammatory properties of PS + CR 
on LPS-stimulated RAW 264.7 cells and CA-induced rat paw edema are likely due to epicatechin and berberine.

\section{Conclusions}

Our results demonstrate that PS $+\mathrm{CR}$ exhibits antiinflammatory properties by decreasing the production of pro-inflammatory mediators $\left(\mathrm{NO}, \mathrm{PGE}_{2}, \mathrm{TNF}-\alpha\right.$, IL-1 $\beta$, and IL-6), suppressing NF- $\mathrm{kB}$ signaling in LPSinduced RAW 264.7 cells. Additionally, the results of the CA-induced rat paw edema assay revealed an anti-edema effect of PS + CR. Furthermore, it is suggested that PS $+\mathrm{CR}$ also inhibits acute edematous inflammation by suppressing mast cell degranulation and inflammatory mediators (COX-2, iNOS, and TNF- $\alpha$ ). Thus, PS + CR may be a potential candidate for the treatment of various inflammatory diseases, and it may also contribute to a better understanding of the molecular mechanisms underlying inflammatory response regulation.

\section{Abbreviations \\ CA: Carrageenan; COX: Cyclooxygenase; CR: Coptis chinensis root; \\ DEXA: Dexamethasone; ELISA: Enzyme-linked immunesorbent assay; HE: Hematoxylin \& Eosin; IL: Interleukin; iNOS: Inducible nitric oxide synthase; LPS: Lipopolysaccharide; MTT: 3-(4,5-dimethylthiazol-2-yl)-2,5-diphenyltetrazolium bromide; NF: Nuclear factor; NO: Nitric oxide; PBS: Phosphate-buffered saline; PG: Prostaglandin; p-l-kBa: Phospho-inhibitor of NF-kBa; PS: Pelargonium sidoides; RIPA: Radio immunoprecipitation assay; TNF: Tumor necrosis factor}

\section{Funding}

This study was supported by the Convergence of Conventional Medicine and Traditional Korean Medicine R\&D Program funded by the Ministry of Health \& Welfare through the Korea Health Industry Development Institute (KHIDI) (grant number: HI15C0185).

\section{Availability of data and materials}

The datasets supporting the conclusions of this article are included within the manuscript. The raw data and materials of current study are available from the corresponding author on reasonable request.

\begin{abstract}
Authors' contributions
SCK and BGM contributed to the design and conception of this study. SMP BGM and JYJ participated in the in vitro studies. SKK, KYK and KHJ carried out the in vivo experiments. Experimental and laboratory analysis was performed by SMP, CWL, YWK and YWC. KHJ did the statistical analysis. The manuscript was drafted by SCK, SKK and CWL. The editing of the manuscript was performed by SCK, IJC and YWK. All authors read and approved the final content of the manuscript.
\end{abstract}

\section{Ethics approval}

All animal experiments were approved by the Animal Ethical Care Committee of Daegu Haany University (Approval number: DHU2016-089) and conducted in accordance with the guidelines for the care and use of laboratory animals at Daegu Haany University.

\section{Consent for publication}

Not applicable.

\section{Competing interests}

The authors declare that they have no competing interests.

\section{Publisher's Note}

Springer Nature remains neutral with regard to jurisdictional claims in published maps and institutional affiliations.

\section{Author details}

'College of Korean Medicine, Daegu Haany University, Gyeongsan 38610, Republic of Korea. ${ }^{2}$ Chungnam National University, Daejeon 34134, Republic of Korea. ${ }^{3}$ Korea United Pharm Inc., Seoul 06116, Republic of Korea.

Received: 19 April 2017 Accepted: 14 January 2018

Published online: 19 January 2018

\section{References}

1. Zhang $X$, Mosser DM. Macrophage activation by endogenous danger signals. J Pathol. 2008;214:161-78.

2. Jang KJ, Choi SH, Yu GJ, Hong SH, Chung YH, Kim CH, Yoon HM, Kim GY, Kim BW, Choi YH. Anti-inflammatory potential of total saponins derived from the roots of Panax Ginseng in lipopolysaccharide-activated RAW 264.7 macrophages. Exp Ther Med. 2016;11:1109-15.

3. Kim SY, Park SM, Hwangbo M, Lee JR, Byun SH, Ku SK, Cho IJ, Kim SC, Jee SY, Park SJ. Cheongsangbangpung-tang ameliorated the acute inflammatory response via the inhibition of NF-kappaB activation and MAPK phosphorylation. BMC Complement Altern Med. 2017;17:46.

4. Fitzpatrick FA. Inflammation, carcinogenesis and cancer. Int Immunopharmacol. 2001;1(9-10):1651-67.

5. Kapadia M, Sakic B. Autoimmune and inflammatory mechanisms of CNS damage. Prog Neurobiol. 2011;95(3):301-33.

6. Laveti D, Kumar M, Hemalatha R, Sistla R, Naidu VG, Talla V, Verma V, Kaur N, Nagpal R. Anti-inflammatory treatments for chronic diseases: a review. Inflamm Allergy Drug Targets. 2013:12(5):349-61.

7. Fujihara M, Muroi M, Tanamoto K, Suzuki T, Azuma H, Ikeda H. Molecular mechanisms of macrophage activation and deactivation by lipopolysaccharide: roles of the receptor complex. Pharmacol Ther. 2003;100(2):171-94.

8. Marsh $\mathrm{CB}$, Wewers MD. The pathogenesis of sepsis. Factors that modulate the response to gram-negative bacterial infection. Clin Chest Med. 1996;17(2):183-97.

9. Watson WH, Zhao Y, Chawla RK. S-adenosylmethionine attenuates the lipopolysaccharide-induced expression of the gene for tumour necrosis factor alpha. Biochem J. 1999;342:21-5.

10. Mendes DA, Soley BD, Prudente AD, Sponchiado G, Ferreira BG, Dos Santos MC, de Andrade AS, Amorim CM, Bresolin TM, Meyre-Silva C, et al. Hydroalcoholic extract of Sapium glandulatum (Vell.) Pax displays potent anti-inflammatory activities through a glucocorticoid receptor-dependent pathway. Phytomedicine. 2016;23(13):1610-20.

11. Cheng YT, Yang CC, Shyur LF. Phytomedicine-modulating oxidative stress and the tumor microenvironment for cancer therapy. Pharmacol Res. 2016;114:128-43.

12. Witte K, Koch E, Volk HD, Wolk K, Sabat R. The pelargonium sidoides extract EPs 7630 drives the innate immune defense by activating selected MAP Kinase pathways in human Monocytes. PLoS One. 2015;10(9):e0138075.

13. Bao Y, Gao Y, Koch E, Pan X, Jin Y, Cui X. Evaluation of pharmacodynamic activities of $\operatorname{EPS}(\mathrm{R}) 7630$, a special extract from roots of pelargonium sidoides, in animals models of cough, secretolytic activity and acute bronchitis. Phytomedicine. 2015;22(4):504-9.

14. Brendler T, van Wyk BE. A historical, scientific and commercial perspective on the medicinal use of pelargonium sidoides (Geraniaceae). J Ethnopharmacol. 2008;119(3):420-33.

15. Tan HL, Chan KG, Pusparajah P, Duangjai A, Saokaew S, Mehmood Khan T, Lee LH, Goh BH. Rhizoma Coptidis: A Potential Cardiovascular Protective Agent. Front Pharmacol. 2016:7:362.

16. Yan D, Ma B, Shi R, Wang T, Ma Y. Involvement of herb-herb interactions in the influences of radix Scutellaria and Coptis Chinensis on the bioavailability of the anthraquinones form Rhei Rhizoma in rats. Eur J Drug Metab Pharmacokinet. 2015:40(1):103-10.

17. Choi YY, Kim MH, Cho IH, Kim JH, Hong J, Lee TH, Yang WM. Inhibitory effect of Coptis Chinensis on inflammation in LPS-induced endotoxemia. J Ethnopharmacol. 2013;149(2):506-12.

18. Kim E, Ahn S, Rhee HI, Lee DC. Coptis Chinensis Franch. Extract up-regulate type I helper T-cell cytokine through MAPK activation in MOLT-4 T cell. J Ethnopharmacol. 2016;189:126-31.

19. Zhao H, Zhou S, Zhang M, Feng J, Wang S, Wang D, Geng Y, Wang X. An in vitro AChE inhibition assay combined with UF-HPLC-ESI-Q-TOF/MS approach for screening and characterizing of AChE inhibitors from roots of Coptis Chinensis Franch. J Pharm Biomed Anal. 2016;120:235-40.

20. Kim K, Kim Kl, Lee J. Inhibitory effects of Cheongsangbangpoong-tang on both inflammatory acne lesions and facial heat in patients with acne 
vulgaris: a randomized controlled trial protocol. BMC Complement Altern Med. 2016;16:21.

21. Watanabe K, Kawamori T, Nakatsugi S, Wakabayashi K. COX-2 and iNOS, good targets for chemoprevention of colon cancer. Biofactors. 2000;12(1-4):129-33.

22. Li Q, Verma IM. NF-kappaB regulation in the immune system. Nat Rev Immunol. 2002:2(10):725-34.

23. Hwangbo M, Jung JY, Ki SH, Park SM, Jegal KH, Cho IJ, Lee JH, Kang SH, Park SD, Ku SK, et al. U-bang-Haequi tang: a herbal prescription that prevents acute inflammation through inhibition of NF-kappa B-mediated inducible nitric oxide synthase. Evid Based Complement Alternat Med. 2014:542825.

24. Tahan F, Yaman M. Can the pelargonium sidoides root extract EPs(R) 7630 prevent asthma attacks during viral infections of the upper respiratory tract in children? Phytomedicine. 2013;20(2):148-50.

25. Wu J, Zhang H, Hu B, Yang L, Wang P, Wang F, Meng X. Coptisine from Coptis Chinensis inhibits production of inflammatory mediators in lipopolysaccharide-stimulated RAW 264.7 murine macrophage cells. Eur J Pharmacol. 2016;780:106-14.

26. Jeong SJ, Kim OS, Yoo SR, Seo CS, Kim Y, Shin HK. Anti-inflammatory and antioxidant activity of the traditional herbal formula Gwakhyangjeonggisan via enhancement of heme oxygenase1 expression in RAW264.7 macrophages. Mol Med Rep. 2016:13(5):4365-71.

27. Blatteis CM, Li S, Li Z, Feleder C, Perlik V. Cytokines, $\mathrm{PGE}_{2}$ and endotoxic fever: a re-assessment. Prostaglandins Other Lipid Mediat. 2005;76(1-4):1-18.

28. Korhonen R, Lahti A, Kankaanranta H, Moilanen E. Nitric oxide production and signaling in inflammation. Curr Drug Targets Inflamm Allergy. 2005;4(4):471-9.

29. Liu ZK, Ng CF, Shiu HT, Wong HL, Wong CW, Li KK, Zhang JF, Lam PK, Poon WS, Lau CB, et al. A traditional Chinese formula composed of Chuanxiong Rhizoma and Gastrodiae Rhizoma (Da Chuanxiong formula) suppresses inflammatory response in LPS-induced RAW 264.7 cells through inhibition of NF-kappaB pathway. J Ethnopharmacol. 2017;196:20-8.

30. Southan GJ, Szabo C. Selective pharmacological inhibition of distinct nitric oxide synthase isoforms. Biochem Pharmacol. 1996:51(4):383-94.

31. Wang D, Dubois RN. The role of COX-2 in intestinal inflammation and colorectal cancer. Oncogene. 2010;29(6):781-8.

32. Mohy El-Din MM, Senbel AM, Bistawroos AA, El-Mallah A, Nour El-Din NA, Bekhit AA, Abd El Razik HA. A novel COX-2 inhibitor pyrazole derivative proven effective as an anti-inflammatory and analgesic drug. Basic Clin Pharmacol Toxicol. 2011;108(4):263-73.

33. Hamsa TP, Kuttan G. Evaluation of the anti-inflammatory and anti-tumor effect of Ipomoea Obscura (L) and its mode of action through the inhibition of proinflammatory cytokines, nitric oxide and COX-2. Inflammation. 2011;34(3):171-83.

34. Coffey M, Phare S, Peters-Golden M. Induction of inducible nitric oxide synthase by lipopolysaccharide/interferon gamma and sepsis downregulates 5 -lipoxygenase metabolism in murine alveolar macrophages. Exp Lung Res. 2004;30(7):615-33.

35. Sugita R, Kuwabara $H$, Sugimoto $K$, Kubota $K$, Imamura $Y$, Kiho T, Tengeiji $A$, Kawakami K, Shimada KA. Novel selective prostaglandin $E_{2}$ synthesis inhibitor relieves pyrexia and chronic inflammation in rats. Inflammation. 2016;39(2):907-15.

36. Brennan FM, Maini RN, Feldmann M. Role of pro-inflammatory cytokines in rheumatoid arthritis. Springer Semin Immunopathol. 1998;20(1-2):133-47.

37. Chu WM. Tumor necrosis factor. Cancer Lett. 2013;328(2):222-5.

38. Cassim B, Mody G, Bhoola K. Kallikrein cascade and cytokines in inflamed joints. Pharmacol Ther. 2002;94(1-2):1-34.

39. Turner MD, Nedjai B, Hurst T, Pennington DJ. Cytokines and chemokines: at the crossroads of cell signalling and inflammatory disease. Biochim Biophys Acta. 2014;1843(11):2563-82.

40. Nguyen DP, Li J, Tewari AK. Inflammation and prostate cancer: the role of interleukin 6 (IL-6). BJU Int. 2014;113(6):986-92.

41. Oh YC, Cho WK, Im GY, Jeong YH, Hwang YH, Liang C, Ma JY. Anti-inflammatory effect of Lycium fruit water extract in lipopolysaccharide-stimulated RAW 264.7 macrophage cells. Int Immunopharmacol. 2012;13(2):181-9.

42. Harris SG, Padilla J, Koumas L, Ray D, Phipps RP. Prostaglandins as modulators of immunity. Trends Immunol. 2002;23(3):144-50.

43. Beloeil H, Ababneh Z, Chung R, Zurakowski D, Mulkern RV, Berde CB. Effects of bupivacaine and tetrodotoxin on carrageenan-induced hind paw inflammation in rats (part 1): hyperalgesia, edema, and systemic cytokines. Anesthesiology. 2006;105:128-38.

44. Lee CW, Park SM, Zhao R, Lee C, Chun W, Son Y, Kim SH, Jung JY, Jegal KH, Cho IJ, Ku SK, Kim YW, Ju SA, Kim SC, An WG. Hederagenin, a major component of Clematis mandshurica Ruprecht root, attenuates inflammatory responses in RAW 264.7 cells and in mice. Int Immunopharmacol. 2015;29:528-37.

45. Sin YM, Sedgwick AD, Chea EP, Willoughby DA. Mast cells in newly formed lining tissue during acute inflammation: a six day air pouch model in the mouse. Ann Rheum Dis. 1986;45:873-7.

46. Mazzari S, Canella R, Petrelli L, Marcolongo G, Leon A. N-(2hydroxyethyl)hexadecanamide is orally active in reducing edema formation and inflammatory hyperalgesia by down-modulating mast cell activation. Eur J Pharmacol. 1996;300:227-36.

47. Stoll LL, ML MC, Denning GM, Weintraub NL. Antioxidant effects of statins, Drugs Today. 2004;40:975-90.

48. Wang JP, Zhou YM, Ye YJ, Shang XM, Cai YL, Xiong CM, Wu YX, Xu HX Topical anti-inflammatory and analgesic activity of kirenol isolated from Siegesbeckia orientalis. J Ethnopharmacol. 2011;137:1089-94.

49. Kim MJ, Ryu GR, Kang JH, Sim SS, Min DS, Rhie DJ, Yoon SH, Hahn SJ, Jeong IK, Hong KJ, Kim MS. Inhibitory effects of epicatechin on interleukin-1 $\beta$ induced inducible nitric oxide synthase expression in RINm5F cells and rat pancreatic islets by down-regulation of NF-KB activation. Biochem Pharmacol. 2004;68:1775-85.

50. PCDP V, Seito LN, di Stasi LC, Akiko Hiruma-Lima C, Pellizzon CH. Epicatechin used in the treatment of intestinal inflammatory disease: an analysis by experimental models. Evid Based Complement Alternat Med. 2012:508902.

51. Morrison M, van der Heijden R, Heeringa P, Kaijzel E, Verschuren L, Blomhoff R, Kooistra T, Kleemann R. Epicatechin attenuates atherosclerosis and exerts anti-inflammatory effects on diet-induced human C-reactive protein and NF-KB in vivo. Atherosclerosis. 2014;233:149-56.

52. Lou T, Zhang Z, Xi Z, Liu K, Li L, Liu B, Huang F. Berberine inhibits inflammatory response and ameliorates insulin resistance in hepatocytes. Inflammation. 2011;34:659-67.

53. Guo T, Woo SL, Guo X, Li H, Zheng J, Botchlett R, Liu M, Pei Y, Xu H, Cai Y, Zeng T, Chen L, Li X, Li Q, Xiao X, Huo Y, Wu C. Berberine ameliorates hepatic steatosis and suppresses liver and adipose tissue inflammation in mice with diet-induced obesity. Sci Rep. 2016;6:22612.

54. Jeong HW, Hsu KC, Lee JW, Ham M, Huh JY, Shin HJ, Kim WS, Kim JB. Berberine suppresses pro-inflammatory responses through AMPK activation in macrophages. Am J Physiol Endocrinol Metab. 2009;296:E955-64.

55. Jiang Q, Liu P, Wu X, Liu W, Shen X, Lan T, Xu S, Peng J, Xie X, Huang H. Berberine attenuates lipopolysaccharide-induced extracelluar matrix accumulation and inflammation in rat mesangial cells: involvement of NFKB signaling pathway. Mol Cell Endocrinol. 2011;331:34-40.

56. Wang Y. Attenuation of berberine on lipopolysaccharide-induced inflammatory and apoptosis responses in $\beta$-cells via TLR4-independent JNK/ NF-KB pathway. Pharm Biol. 2014;52:532-8.

\section{Submit your next manuscript to BioMed Central and we will help you at every step:}

- We accept pre-submission inquiries

- Our selector tool helps you to find the most relevant journal

- We provide round the clock customer support

- Convenient online submission

- Thorough peer review

- Inclusion in PubMed and all major indexing services

- Maximum visibility for your research

Submit your manuscript at www.biomedcentral.com/submit
) Biomed Central 